\title{
Anatomi dan Strategi Bisnis Industri Tekstil Indonesia pada Dasawarsa 1990-an
}

\author{
Oleh : Suwarsono
}

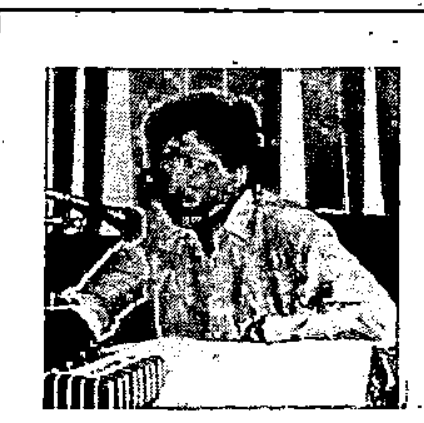

Suwarsono, lahir di Bojonegoro, 25 Mei 1957 menempúh pendidikàn $S 1$ di Fakultas Ekonomi Universitas Islam Indonesia sedangkan S2 di Univer sity of Hawaii dan PAMI ( Pacitic Asian Management Institute). Pernah membuat Karya Tulis Studi Kelayakan Proyek - AMP, Pembangunan dan Perubahän Sosial - LP3ES, Analisis Lingkungan Bisnis, Negara Berkembang. Sekarang manjabat sebagai Direktur WARPLUS dari tahun 1992 hingga sekarang, dan menjadi Dosen Fakultas Ekonomi Universitas Islam Indonesia.

Pada masa lalu, ketika tingkat turbulensi lingkungan bisnis belum tinggi, perencanaan perusahaan (corporate plan) disusun dengan lebih memperhatikan faktor internal perusahaan: Ketika itu, peran analisis keuangan terkesan amat dominan. Perencanaan disusun untuk jangka waktu pendek dan hanya dengan satu skenario. Lingkunganekstemal selalu berjalan seiring dengan kepentingan perusahaan. Oleh karena itu, perhatian pada pengaruh lingkungan bisnis terhadap kegagalan atau keberhasilan perusahaan menjadi tidak sangat dipentingkan. Lingkungan Bisnis menjadi faktor yang tidak berperan secara signifikan.

Kini ketika lingkungan bisnis sering berubah -- bahkan sering tanpa sinyal pasar yang tránsparan -- pendekatan perencanaan perusahaan tersebut telah mulai banyak ditinggalkan, setidaknya itulah yang dianut Ansoff dan Mc Donnell (1990). Ilmu dan seni perencanaan telah mengalami pergeseran yang signifikan.

Perencanaan lebih bersifat jangka panjang dengan memberikan perhatian besar pada lingkungan bisnis dalam menciptakan peluang (opportuntiess) dan ancaman (threats) bisnis, Skenario tak mungkin lagi tunggal, setidaknya berskenario ganda, kalaulah bukan banyak. Variabel internal tetap diperhatikan, akan tetapi lebih berfungsi sebagai antisipasi terhadap peluang dan ancaman bisnis yang ditimbulkan oleh lingkungan makro dan mikro. Analịsis pemasaran, dengan demikian.Kemudian memperoleh tempat yang lebih terhormat, sekalipun tak berarti bahwa pèrencanaan modem ini sepenuhnya meninggalkan peran manajemen fungsional yang lain, khususnya manajemen keuangan.

Tulisan ini hampir sepenuhnya mengikuti paradigma tersebut. Paradigma 
yang lebih memberi kesan hati-hati (prudent) dan sekaligus dinamis. Oleh karena itu, pada bagian awal akan dijelaskan tentang lingkungan makro -- khususnya lingkungan ekonomi dan politik -- dan lingkungan industri (persaingan) dari industri tekstil Indonesia. Dari sini diharapkan terlihat profil lingkungan bisnis (environmental threats and opportunity profiles (ETOP) yang mengitarinya.

Barulah kemudian setelah anatomi lingkungan selesai dikerjakan, anatomi industri menyusul dibuat untukmengetahui kekuatan (strengths) dan kelemahan (weakwesess) yang melekat padanya. Diharapkan dapat dilihat profil keunggulan strategis (strategis adventage profiles (SAP). Inilah bagian kedua dari kertas kerja. Dengan demikian, dalam pengertiannya yang amat longgar, kertas kerja ini mengikuti pola pikiryang ada dālam analisis. TONS.

Dengan menggabungkan kedua bagian tersebut, diharapkan dapat diketahui posisi pasar industri tekstil Indonesia di pasar global. Setidaknya dapat diketahui apakah kini berada pada posisi pasar yang menjanjikan aliran kasmasuk (cash inflow) ataukah berada pada posisi pasar yang mengisyaratkan pertanyaan tentang prospeknya dikemudian hari.

Barulah kemudian rancangan awal perumusan strategi dapat dirumuskan. Disamping itu juga tetap perlu diingat bahwa perumusan strategi bukanlah jaminan akan keberhasilan, masih ada tahapan lain yang lebih penting, yakni implementasi strategi yang dalam hal ini cukup panjang untuk diterangkan.

Industri tekstil, dalam sejarah perkembangannya, memiliki banyak karakteristik yang khas. Industri tekstil adalah salah satu jenis industri yang tertua di Indonesia. Lahir, tumbuh subur, menyusut dan berkembang lagi sejak sebelum kemerdekaan. Mengalami pasang surut yang cukup berfluktuatif. Ia juga selalu memberikan sumbangan penyerapan tenaga kerja yang banyak. Kalaulah bukan yang terbesardibanding semua jenis industri yang lain. Bahkan, ia pernah menjadi tulang punggung pemasok kebutuhan sandang. Pada industri ini kepentingan banyak pihak juga terlibat. Pemermtah, produsen - besar, sedang dan kecil dan rakyat banyak sebagai konsumen dan pemások tenaga kerja. nampaknya tak ada satupun yang memiliki kepentingan yangharusdan perlu dititipkan. Oleh karena itu tidak heran, jika dalam sejarahnya, industri ini tak pernah sepi dari konflik politik. Dengan kata lain, sejak semula hingga kini, industri tekstil sarat dengan peran ekonomis dan politis (Palmer dan Castless 1965, Palmer 1972, Fill 1980, Macintyre 1991).

Disamping itu semua, kini setelah mengalami masa surut yang berkepanjang an sejak awal Orde Baru sampai pertengahan dasawarsa 1980-an industri ini menjadi șalah satu tulang punggung terpenting penghasil devisa negara. Belakangan ini menempati sebagai ujung tombak pertama, diikuti oleh kayu dan pariwisata. Sejak pemerintah memberikan perhatian yang besar pada peningkatan ekspor non-migas karena semakin melemahnya peran migas -- diawal tahun 1985, industri tekstil sepertinya memperoleh momentumnya kembali untuk bangkit.

Bahkan, rasanya tidak keliru jika dikatakan, bahwa ekspor merupakan "an engine of growth" dari industri tekstil di Indonesia. Oleh karena itu, sudah selayaknya jika perhatian utama dalam melakukan analisislingkunganbisnismakro 
adalah dengan melihat beberapa karakteristik yang melekat pada pasar internasional: target geografis, segmentasi pasar, perilaku konsumen dan pesaing.

Dari mula sampai dengan kini, target utama industri tekstil Indonesia adalah pasar Amerika Serikat. Ini dapat dipahami, karena Amerika Serikat merupakan pasar yang amat besar dan potensial. Amerika Serikat adalah negara pengimpor garment terbesar di dunia dan hanya memiliki halangan memasuki try) yang rendah. Konsumen amat heterogin sehingga memungkinkan untuk terjadinya pemasaran massal barang yang berasal dari negara yang berada pada urutan belakang sebagai pengekspor seperti Indonesia. Pasar yang demikian juga cocokbagi barang yang "inenpensive", kalaulah bukan murah dan berkwalitas rendah. Lebih dari itu, saluran distribusi juga terbuka dengan amat lebar. Tak diharuskan membangun sendiri. Konsumen Amerika juga memiliki pengetahuan yang cukup tentang tekstil Indonesia. Jepang dan Masyarakat Eropa sebagai sasaran berikutnya. Barulah belakangan ini, Jepang mendapat perhatian yang lebih sungguh-sungguh.

Namun , demikian, sekalipun Amerika Serikat tetap dijadikan prioritas utama paling tidak untuk jangka pendek yang menengah -- hendaknya tetap perlu diingat bahwa Amerika Serikat adalah salah satu anggota MFA (Multi Fibre Arrangement) yang setiap saat akan semakin memperkuat halangan memasuki pasarbagi industri tekstil Indonesia. Kasus GSP (Generalized System of Preference) yang baru saja muncul kepermukaan hanyalah. sekèdar contoh untuk diulang dan muncul dikemudian hari.

Oleh karena itu, untuk keperluan jangka waktu menengah yang panjang, In- donesiaperlu melakukan diversifikasi pasar dengan mencoba melakukan eksploitasi pasar lain, khususnya yang bukan anggota penandatangan MFA. Jepang, Australia, Timur Tengah sepertinya merupakản pasar potensial yang tidak boleh ditinggalkan lagi. Momentum meningkatnya Yen dapat dimanfaatkan sebagai dorongan pendahuluan untuk melakukan ekspor. Rasanya, berita tentang lesunya ekonomi Jepang belum dapat dipercaya sepenuhnya: Kalaulah benar, nampaknya tak hendak berpengaruh besar pada barang tekstil, karena ia tak termasukbarang yang menyita banyak pendapatan. Hanya barang konsumsi. Tentu saja tetap perlu diingat bahwa berbisnis di Jepang memiliki banyak kekhususan. Meningkatnya tenaga kerja Indonesia di TimurTengah juga merupakan pasar potensial dimasa depan.

Diversifikasi pasar ini akan nampak lebih penting karena temyata hanya Indonesia saja yang memanfaatkan pasar AS. Negara pesaing yang jauh lebih tangguh dibanding Indonesia, misalnya Taiwan, Korea Selatan, Singapore, Hongkong, Thailand, Malaysia juga melakukan hal yang sama. Mereka memiliki kompetensi dan kwalifikasi yang lebih tinggi. Mereka juga lebih dahulu memasuki pasar. Bahkan yang terpenting adalah pangsa pasar (market share) rata-rata yang mereka miliki jauh lebih besar dibanding Indonesia. Indonesia hanya memiliki porsi yang amat kecil (Hill, 1991).

amat kasar, tulisan ini memberanikan diri menyatakan bahwa pangsa pasar relatif. Indonesia jika misalnya dibandingkan dengan salah satu pesaing utamanya (tak peduli Thailand atau Taiwan), maka juga terlihat sebesar kurang dari satu. Dengan demikian, jika menggunakan alat analisa matriks BCG (Boston Consulting Group) 
setelah sedikit dilakukan modifikasi dengan mengganti SBU (Strategic Business Unit) dengan negara,' maka posisi Indonesia barangkali masih berada pada kolom "tanda tanya". Pasar secara keseluruhan memang masih tumbuh dengan tingkat pertumbuhan yang tinggi, akan tetapi bagian pasar yang dikuasai Indonesia belum menunjukkan adanya jaminan aliran kasmasuk yang besar dan konsisten untuk jangka panjang.

Jika situasinya demikian, maka mau tak mau strategi bisnis yang agresif dalam memperbesar pangsa pasar tak dapat tidak harus menjadi pilihan, terkecuali bersedia mengalami ' keajegan. Investasi jangka panjangmasih diperlukan. Kaskeluarmasih harus ditanggung. Promosi dagang masih menjadi kebutuhan. Sayangnya, tak ada kemungkinan untuk menggunakan "mode od entry" selain melalui ekspor. Tak mungkin melalui FDI (Foreign Direct Invesment) dan lisensi (Porter, 1990). Oleh karena itu, pilihan untuk membuka pasar selain Amerika Serikat sepertinya sudah menjadi keharusan.

Siapkah industri tekstil Indonesia? Pertama, tergantung pada stabilitas ekonomi makro Indonesia sendiri. Hendaknya pemerintah tetap' perlu memberikan dukungan yang kondusif. Nilai tukar uang dannilai tukarperdagangan (terms of trade) perlu dijaga. Pemerintah juga perlu tetap memberikan insentif rendahnya biaya masuk bahan baku yang diperlukan. Harap tetap diingat bahwa ketika sukses ekspor industri tekstil dicapai, peran pemerintah amat besar dalam memberikan proteksi ketika masa ISI (Import Substitution Industry) berlangsung, sebelum masa ELI (Eksport Led Industrialization) dimulai (Wie 1990).

Kedua, bergantung pada kondisi intemal industri tekstil itu sendiri. Jangan lupa bahwa industri tekstil selalu dipenuhi oleh intrik politik tingkat tinggi (Makarim dan Nibisono, 1989 dan Macintyre, 1991). Ini terjadi karena banyaknya asosiași kelompok kepentingan yang ada dalam industri tersebut.

Disamping itu, industri juga memiliki besaran usaha yang amat variatif, sejak dari yang sangat padat teknologi dan modal sampai dengan yang bersifat kecil dan padat karya.

Lebih penting dari itu, ternyata industri ini tak hanya diisi oleh modal domestik, tetapi juga secara bersamaan didominasi oleh modal asing. Bahkan, yang disebut terakhir ini memiliki peran yang semakin besar, khususnya pada industri hulu. Merekalah yang merintis mengembangkan integrasi kebelakang dan kedepan. Peserta dari MDC (Menly Developed Countries) seperti dari Korea, Hongkong, Taiwan semakin banyak, setelah sebelumnya diisi oleh Jepang.

Persoalan ini menjadi lebih kusut karena beberapa aspek lain dalam ekonomi industri (industrial economics) temyatajuga tak mendukung. Skala ekonomi dan kurve belajar belum dapat diperoleh, khususnya karena rendahnya pangsa pasar yang dimiliki. Biaya transaksi, khususnya biaya yang mendapatkan peluang informasi pasar, amat mahal. Disaat yang sama, industri ini juga menuntut biaya promosi yang amat besar.

Kondisi internal menjadi semakin sulit ketika ternyata soal kuota ke negara MFA yang menjadi wewenang pemerintah Indonesia untuk membagi tak kunjung tuntas. Ada persoalan transparansi pengambilan keputusan, konsistensi, rasionalitas dan kelambatan administratif (Hill, 1991). Nampaknya masih belum dapat sepenuhnya lepas dari pertimbangan soal 
politik.

Namun demikian, nampaknya ada pilihan strategi internal yang akan netral, yang berkaitan dengan pengembangan produk. Jika selama ini segmen pasar yang dituju lebih banyak-pada golongan menengah ke bawah dengan produk berkwalitas rendah dan hanya murah, maka bukankah sudah tiba waktunya untuk membidik segmen pasar yang sedikit berselera lebih tinggi, kalaulah bukan ekslusif. Rasanya, sudah tiba saatnya untuk melakukan "upgrading" barang. Tidak terus menerus mengandalkan strategi "overall cost leadership". Akan tetapi, strategi. itu tak perlu ditinggalkan. Mulai dicoba dikenalkan strategi fokus, dengan sengaja memilih segmen pasar tertentu yang memiliki permintaan potensial yang besar dan ajeg (Porter 1990 dan Kotler 1991). Pilihan ini rasanya tepat dikenalkan pada wilayah pasar baru yang dicoba untuk dimasuki, seperti Jepang dan sebagian Masyarakat Eropa.

Kini, industri tekstil Indonesia menjadi primadona utama dalam menghasilkan devisa negara. Akan tetapi, dalam jangka panjang bukan sepenuhnya tak ada ancaman, jika sasaran pasar pokok hanya ditujukan pada Amerika Serikat saja dan hanya menggantungkan pada satu jenis kwalitas barang, yakni yang bermutu rendah dan berharga murah.

Nampaknya sudah tiba waktunya untuk mempertimbangkan melakúkan pilihan segmen pasar baru dengan memperkenalkan jenis barang yang lebih berkualitas. Sangat diharapkan mencapai tahapan diferensiasi (bukan diversifikasi) barang. Lebih penting dari itu, industri tekstil perlu membuka wilayah geografis baru, khususnya negara-negara yang belum menandatangani perjanjian MFA.
Nampaknya Jepang menjadi pilihan yang paling mendesak.

Untuk itu semua dukungan pemerintah masih tetap diperlukan, khususnya dalam menyediakan lingkungan bisnis yang kondusif dan perannya sebagai mediator konflik. Yang terakhir ini diperlukan untuk membantu mengelola konflik kepentingan yang selama ini muncul dikalangan industri tekstil. Lebih dari itu semua, diperlukan kesiapan industri tekstil itu sendiri untuk selalu mengantisipasi perubahan lingkungan bisnis yang semakin sering terjadi.

\section{Daftar Bacaan}

Ansoff, Igor dan McDonnell, 1990, Implanting Stralegic Management. New York, Prentice Hall.

Max, Arnold C, dan Mujluf, Nicolas S, 1984.

Straicgic Managemen, New Jersey, Prentice Hall.

Hill. Hall. 1980, "The Economics of Recent Changes in the Weaving Industry." Bulletin of Indonesian Economic Studies (BIES), Vol. XVI, No. 2.

1991, "The' Emperor's Clothes Can Man

Be Made in Indonesia", BIES, Vol. 27 No. 3. Kotler, Philip. 1991. Marketing Management. New Jersey, Prentice Hall.

Aakarim dan Wibisono. 1989. "The Politics of Indonesian Textile Policy, The Interest of Goverment Agencies and The Private Sector", BIES, Vol. 25, No. 1.

Palmer, Ingrid dan Castles, Lance, 1965, "The Textile Industry", BIES, No. 2.

Palmer, Ingrid, 1972, Textiles in Indonesia Problems of Import Substitution, New York, Praseger.

Porter, Michael E, 1990, Competitive Strategy, New York, The Free Press.

Macintyre, Andrew, 1991, Business and Politics in Indonesia, Sidney, Allen.

Wie, Thee kiam, 1990, "Perubahan Ke Arah Industrialisasi Berorientasi Ekspor. Peluang dan Rintangan", Prisma, No. 3. 